\title{
Developing Problem-Solving Skills With Case Study In A Conceptual Management Course
}

Wei He, Indiana State University, USA

\begin{abstract}
Few management courses highlight the development of students' problem-solving skills as a learning goal despite the popularity of solving management problems as a routine job for managers. Drawing on the pedagogies of problem-based learning and case teaching, this paper presents a problem-solving approach of case study and applies it to a set of 14 Harvard Business Review cases to develop problem-solving skills in a typical conceptual management course Organizational Behavior. It explains the detailed requirements of the problem-solving approach of case study step by step, specifies the case references and their suitable topics respectively, describes the organization and process of a problem-solving case study session, illustrates an exemplary case study out of the 14 cases, and discusses the effectiveness and implications of the problem-solving pedagogy. The paper has three folds of contribution to management education: It proves both the necessity and feasibility of developing students' problem-solving skills in a conceptual management course; it provides other instructors of Organizational Behavior or Management with a valid, ready-to-use pedagogy and quality teaching materials to improve the relevance and effectiveness of their teaching; and it may inspire more instructors of management courses to explore their own comfortable pedagogies in developing business students' skills.
\end{abstract}

Keywords: Problem-Solving Skills; Case Study; Management Pedagogy; Organizational Behavior

\section{INTRODUCTION}

1 n AACSB's (2013) latest steering document for business school accreditation, AACSB Assurance of Learning Standards: An Interpretation, "problem-solving" was exemplified as one of the key learning goals, side by side with communication skills, ethical reasoning skills, language skills, technology skills, and so on. Martell $(2005,2007)$ confirmed that problem-solving is one of the 11 most popular learning goals adopted by AACSB-accredited and candidate business schools through her two massive surveys of deans of AACSB member schools. Along with the academic advocacy of problem-solving is the fact that problem-solving often appears on the list of employers' most-wanted skills for college graduates in numerous surveys (e.g., Bigelow, 2004; Maxwell, Scott, Macfarlane, \&Williamson, 2010).

For most quantitative or analytical courses in business curriculum, problem-solving is inarguably a top learning goal. Although lack of published empirical research on the specific learning goals of various quantitative business courses for assurance of learning expected by AACSB accreditation, problem-solving is commonly specified as one of the key learning goals or objectives for such courses as Business Statistics, Operation Management, Accounting, and Finance by the author's own school and several other business schools whose business curriculum assessment plans are available online (e.g., California State University, Long Beach, 2014; Illinois State University, 2010). In contrast, more qualitative, conceptual courses such as Organizational Behavior, Management, Strategic Management, Business and Society, International Business, and so on rarely describe problem-solving as an assurance of learning goal in these schools' assessment plan, although again there is a lack of published literature on the learning goals of conceptual management courses for assurance of learning and AACSB accreditation. Moreover, management textbooks (such as those popular ones by Robins \& Judge, 2015; Daft, 2014; 
Hill, Jones, \& Schilling, 2015) usually use verbs like "define", "describe", "understand", "explain", "discuss", "compare and contrast" to describe the books' and chapters' learning goals. These verbs actually represent only the two lowest-level learning goals in Bloom's learning taxonomy - knowledge and comprehension (Bloom, Engelhart, Furst, Hill, \& Krathwohl, 1956). They have not reached the higher levels of learning - application, analysis, synthesis, and evaluation, through which students can benefit most from the problem-solving process. Few management textbooks even mention problem-solving as any sort of learning goals. Readers can hardly find the term "problem-solving" in most of these management textbooks' subject indices.

Does such a wide ignorance of problem-solving in conceptual management courses imply that these courses simply do not have to develop students' problem-solving skills at all and would rather merely focus on imparting knowledge instead? Not really. Take the example of a popular management course (also often a business core course) - Organizational Behavior, which studies workforce behavior at the individual, group, and organizational levels so as to improve management effectiveness and enhance organizational performance. Managers were found to spend two thirds of their time on dealing with human issues such as networking, communication, and personnel routines while only up to one third on traditional management functions such as decision making, planning, and controlling ; and successful managers spend even as much as $87 \%$ of their time on managing those behavioral issues (Luthans, 1988). Obviously they need to solve problems related to interpersonal issues as their daily routines, if not more often than to solve those operational or financial problems. The reason that few Organizational Behavior classes (as well as other conceptual management courses) identify problem-solving as a learning goal despite the popularity of behavioral problems in the workplace can be partially attributed to the general criticism of management education for lack of practicality, comprehensiveness, and soft skill development by Porter and McKibbon (1988), Leavitt (1989), Mintzberg (2004), and Pfeffer (Pfefer \& Fong, 2002).

The author argues that another significant technical reason also hinders Organizational Behavior as well as other management courses from emphasizing problem-solving skills as a learning goal in their classroom - the lack of a systematic approach and relevant teaching materials for the development of problem-solving skills in these courses. Management instructors and their textbooks usually use various experiential exercises and mini-case studies to help the students apply the conceptual knowledge learned from their classes. The experiential exercises are mostly designed more for students to better understand the concepts and theories of the course than to develop their skills in coping with practical problems relevant to the course subjects. Some of the exercises, such as the popular Paper Tower Building team project or the Ugly Orange negotiation role play, are more entertaining than educational, with doubtful relevance and validity to students' learning goals. The mini-case studies for the textbook chapters, the continuing case studies throughout the book, and the comprehensive case studies in the end of the textbooks all come with detailed questions about the cases. This format sometimes turns all these three types of case studies into sort of "Q \& A" sessions or reading comprehension tests rather than valid, simulative learning opportunities to develop students' skills in solving practical problems. One thing is obvious - nobody would raise all those case specific questions for managers in the real world. Instead managers have to define the problem, analyze causes, prescribe alternatives, make a decision, and implement it all by themselves. Conceptual management courses therefore desperately need a more systematic (rather than random) method and relevant (rather than fancy) materials to develop students' skills in solving management problems as many quantitative courses do.

Based on the previous pedagogical research findings on problem-solving and case teaching as well as the author's two decades of experience in teaching management courses, this paper presents a unique approach of developing problem-solving skills in a conceptual management course - Organizational Behavior. It adapts the classical problem-solving model, picks a set of Harvard Business Review (HBR) cases that match the various topics of Organizational Behavior respectively, and multiply practice and reinforce the students' problem-solving skills through both individual and group case study activities. It not only provides the students with a series of opportunities to apply the concepts and theories of Organizational Behavior to complex, reality-based management scenarios and let them see how Organizational Behavior knowledge works in reality, but it also (perhaps more importantly) makes them to actively and creatively think and solve practical problems like a manger without relying on predefined case study questions.

In the following parts, this paper will first review relevant literature on problem-solving and case teaching, making an argument that case study can be used as an effective pedagogy of developing problem-solving skills in 
conceptual management courses. Then it will describe the method and teaching materials used in the paper. Next it will illustrate how to apply the problem-solving case study approach to a sample case out of the HBR cases. Finally it will discuss the effectiveness and limitations of the approach.

\section{LITERATURE REVIEW}

\section{Problem-solving Skills and Problem-Based Learning}

A problem is considered a discrepancy between desired goals and the existing state (Pounds, 1969; Daft, 2014) or a difficulty restraining from achieving goals (Kinicki \& Williams, 2013). Management or organizational problems are routines to managers (Landry, 1995) and always on their agenda and attract their attention (Daft, 2014). Problem-solving is therefore to identify the gap between reality and goals and take actions to resolve it (Shermerhorn, 2013). Problem-solving and controlling are necessary means to assure the accomplishment of goals and plans (Kotter, 2001). To put it simple, managers are problem solvers (Shermerhorn, 2013).

Problem-solving skills are often considered one of the most desirable employment skills by employers (Knight \& Yorke, 2004). Many companies provide problem-solving skill training to their managers and selfmanaged teams (e.g., quality circle) (Shonk, 1997). As one of the Assurance of Learning goals for AACSB accreditation, problem-solving skills are defined by the author's school as the ability to "solve business problems by applying appropriate technology, tools, and decision-making techniques," with such specific learning outcomes as articulating the main issues of a business decision, using evidence in the decision process, and justifying conclusions and develop recommendations (Indiana State University, 2013). Hambur, Rowe, Tu Luc, and Australian Council for Educational Research (2002) specified several stages of problem-solving across disciplinary areas with common elements - identification and analysis of problems and causes; selection and organization of relevant information; representation; identification of alternative solutions; and application and evaluation of solutions.

Perhaps the best known cross-disciplinary theory about problem-solving is the problem-based learning pedagogy. Initiated by the faculty at the medical school of McMaster University of Canada in the 1960's, problembased learning was later widely introduced into other educational disciplines such as chemistry, physics, biology, and engineering as well medical education in other institutions. It differentiates itself from the traditional pedagogy of passive, instructor-centered lecture as an active, student-centered learning of thinking strategies as well as subject knowledge through the student's problem-solving experience. Under the problem-based learning pedagogy, students are asked to work in groups to solve an unstructured problem (such as diagnosing certain symptoms) designated by the instructor. The instructor is supposed to encourage, support, advise, and monitor the learning activities of the students as a facilitator (Schmidt, Rotgans, \& Yew, 2011). Thus problem-based learning is believed to be able to help the students more effectively master relevant knowledge, build problem-solving skills, promote self-directed learning, improve collaboration, and inspire further learning and exploratory motives (Hmelo-Silver, 2004; Brownwell \& Jameson, 2004). To put it another way, students learn how to learn through a procedural framework of problem-based learning (Miller, 2004). This kind of continuing learning ability built up through problem-solving experience will greatly benefit the students' future career after graduation because it is exactly what employers look for out of their employees.

Despite its popularity in medical education and other disciplines, however, problem-based learning has been less recognized in management education. As PBL Insight (a primary publication on problem-based learning) found, only six among the 106 universities and colleges that adopted problem-based learning pedagogy applied it to business classes (Anonymous, 2001). Moreover, since the publication of a special issue on problem-based learning in the Journal of Management Education (one of the two major journals focusing on management education) in 2004, only 10 articles have been published in the same journal and three articles in the Academy of Management Learning \& Education (the top tier journal on management education) that are related to problem-based learning (via subject search of problem-based learning) over the past decade. The reason for the unpopularity of problembased learning in management education is most likely that there is already a century-old problem-solving pedagogy in this discipline - the case study method, which provides richer information to students, deal with more unstructured and variety of functional and comprehensive problems, and better develop students' situational awareness and understanding than the problem-based learning pedagogy (Smith, 2005). Thus AACSB Assurance of 
Learning Standards (AACSB, 2013) cited case study as an example of specific learning objectives for the learning goal of problem-solving.

\section{Case Study and Problem-Solving}

Teaching business classes with case study originated at Harvard Business School (HBS) in 1912. Today, A case is defined as "a description of an actual situation, commonly involving a decision, a challenge, an opportunity, a problem or an issue faced by a person, or persons, in an organization." (Erskine, Leenders, \& Mauffette-Leenders, 2003, p. 9) Thus, case study is a "partial, historical, clinical" examination of a business situation confronting a manager or a management team that encourages students to participate in analyzing the specific situation, framing alternative actions, and implementing the solution chosen under the complexity and ambiguity of the practical world (Barnes, Christensen, \& Hansen, 1994). Although a variety of case study emerged lately (Mesny, 2013), such as exemplary or benchmarking case study and illustrative or evaluative case study (Mo \& He, forthcoming), case study adopted in most business schools and classes are still the traditional, HBS style that focuses on analyzing and solving real-life business problems confronting managers at a certain time (Barnes, Christensen, \& Hansen, 1994). The present paper follows this traditional line of case definition and case study.

In addition to building students' skills of analysis, decision making, communication, teamwork, and so forth (Mauffette-Leenders, Erskine, \& Leenders, 2001), case study especially suits the purpose of developing students' problem-solving skills because it well serves three types of learning goals - cognitive, affective, and practical (Mesny, 2013). First of all, the case study method takes students beyond lower-level cognitive learning goals of comprehension (knowledge), remembering (recall), and application in Bloom's learning taxonomy (Bloom, et al., 1956; Krathwohl, 2002) to higher-level learning goals of analysis (critical thinking), synthesis (creative thinking), and evaluation (judgment). In problem-solving case study, students are personally involved in active learning activities such as critical thinking, discussion, challenging, debate, and brain storming. All these activities need the students to take initiative in their own learning rather than to passively listen to lectures, take notes, memorize theories, and take designated knowledge tests.

Case study can also contribute to the affective domain of learning, or the personalization and internalization of students' affective experience of learning embedded with their personal values, attitudes, and motives that will influence their future actions (Krathwohl, 2002; Smith, 1987). Problem-solving case study asks students to take the role of the decision maker in the case, assuming most of the stress, anxiety, challenge, and trade-off faced by a manager in business reality. The excitement and satisfaction that students experience in problem-solving case study are quite popular among case teaching classes (Mauffette-Leenders, et al,. 2001). The impact of this type of empathy or emotional involvement in case study sometimes overwhelms that of other pedagogies in management education on students' attitudes and subsequently their action. People tend to better remember those experiences that impress them most, which in turn intentionally or unintentionally direct their behaviors in the future when similar scenarios occur.

Last but not least, despite some controversy and criticism of the case teaching pedagogy (e.g., Mintzberg, 2004), case study still provides a better opportunity for experiential learning and practicum than many other pedagogies in business education. Considering the resource scarcity, risk, and learning efficiency, business students cannot be educated all through apprenticeship type on-the-the-job training. And not all business subjects and skills can be taught through internship, especially those conceptual management courses. Therefore, reality-based, welldesigned case study, as those problem-solving cases advocated by the traditional HBS style of case teaching, can serve business students as an experiential learning activity the same way as labs to medicine or science students or mock courts to law students. Case study can surely teach more to students about business practices and build their street smart (as well as book smart) than many other pedagogies such as lectures and classroom exercises. Especially for management courses, case study particularly fits the teaching and learning of behaviors and interpersonal relations (Bilimoria \& Fukami, 2002). 


\section{METHODS}

\section{The Problem-Solving Approach of Case Study}

The problem-solving model guiding the case studies presented in this paper was originally inspired by Gordon's (2002) "diagnostic approach" to Organizational Behavior study. Her diagnostic approach defined the four steps of description (collecting data through interview, observation, etc.), diagnosis (identifying influential factors with application of theories), prescription (proposing solutions), and action (implementing and evaluating solutions). The model used in this paper also looks similar to the classical or rational model of decision making, which is widely introduced in all management textbooks (for example, Daft, 2014; Kinicki \& Williams, 2013; Shermerhorn, 2013) and is very familiar to most business students. The classical model typically describes decision making as a six-step process of recognition of decision requirement, analysis of causes, development of alternatives, selection of desired alternatives, implementation of chosen alternatives, and evaluation and feedback (Daft, 2014). The approach used in this paper adapted and simplified these two models in accordance with the special need of building problem-solving skills in a management class with a unique set of cases collected (see Table 1 in the next section). It consists of four steps - identifying problem, diagnosing causes, prescribing alternatives, and making a decision and its implementation plan.

Step I: Identifying problem. After laying out a big picture through a brief review of the case background information (such as the company's products, industry, history, sales, number of employees, ownership structure, and the main characters and their positions in the case), students are asked to identify one primary problem in the case that the organization or manager needs to solve immediately. They are advised to focus only on spotting the main problem in this very first step rather than to discuss how the problem has happened; that is, not to confuse the problem in the case with its causes, which are expected to be examined in the next step. The students are also advised that identifying the right problem is as important as solving it because a good decision could only be made out of a right problem, since all the subsequent parts of their problem-solving process would focus on the major problem they identified. Otherwise they could end up with the GIGO effect ("garbage in, garbage out").

Step II: Diagnosing causes. Having identified a major problem, now students need to find out what have caused the problem. They are encouraged to use the concepts, theories, and/or models learned from the class to guide their cause analysis. Given that each case in this class is purposefully selected to largely fit certain topic in a chapter (see Table 1 in the next section for details), this step is a good opportunity for the students to apply the conceptual knowledge that they are supposed to study in the management course. Furthermore, students are especially reminded not to give a laundry list of bulletin points as possible causes; instead, they need to think over and prioritize the causes, reveal the relationships or patterns among various causes, and present an integrative big picture of causality, hopefully with a diagram. They are also advised to cite specific evidence and facts from the case to support their analyses. All in all, this diagnostic step emphasizes that students need to have an overall understanding of what has happened to the problem, seeing both the trees and the forest. Such an overall analytical and integrative skill is what the students would need most in the future as a manager who needs to persuade his or her boss, board, or customers or as a consultant who needs to convince his or her clients.

Step III: Prescribing alternatives. Based on the previous steps of work, students subsequently need to think thoroughly about alternative solutions to the specific problem identified and its causes diagnosed. They are advised to bring up several major, realistic, and independent (or exclusive) alternatives. Next they need to compare and evaluate the alternatives in terms of their pros-and-cons, feasibility, risk, and/or cost-effectiveness of the major alternatives in both short and long runs. They are encouraged to use the "what...if..." model to assist alternative development. Very often each alternative may have its own advantages and disadvantages as well, and it can be very difficult to pick a choice among major alternatives. This is just how this type of case study can contribute to the development of students' problem-solving skills - it helps the students practice their problem-solving skills like real world managers in dealing with critical challenges involved in any business decisions - the high stake, uncertainty, ambiguity, stress, risk, and contradictory options. Therefore it is worth analyzing all major alternatives and letting the students understand the dilemma and trade-off of problem-solving as a business routine for managers in the real world. 
Step IV: Making a decision and its implementation plan. The most critical part of the entire problemsolving process is to make a choice among alternatives and develop subsequent action plan in details, despite the ambiguity, uncertainty, and risk of the decision situation. This is also the step that should be emphasized most in a problem-solving case study class. Of course, students are reminded that there is no such thing as a standard answer to a problem-solving case, just as in the real business world no manager would know for sure beforehand whether his or her choice of decision would succeed or fail before things really happen. There is no doubt that a case study with an answer key could help students' learning. But any good answer would be no match for the student's experiential learning of decision making under ambiguity, uncertainty, and risk. Thus it is the decision making process other than its results (i.e., knowing whether a student's analysis is correct or not) that really simulates the real managerial experience and builds up the students' problem-solving skills. The students are also advised that managers may pick different choices subject to their personality (e.g., aggressive or risk-averse), past experience, personal values, and so on. Thus, as long as they can well justify their choices of alternative after critical thinking and develop detailed action plan under their choice, the students will be graded as equally as those who may follow the majority's opinions in the class.

Specifically, students are advised to spend more time on how they will carry it out after picking their choice of decision alternatives. They are asked to prepare detailed action plan that may include (but not limited to) answers to these questions: Where to start or who should take the initiative? What's next? What's your contingency plan if your previous action cannot work out? What kind of feedback signs or metrics would you look at and how would you modify your implementation plan accordingly down the road?

Of course, there is a significant difference between the problem-solving approach used in this paper and the classical decision making model - the former lacks the post-action evaluation and feedback step of the latter. It is an understandable limit of all types of case study since any case is merely a simulation of business reality other than the reality per se. In a real business situation the effects of the problem-solving decision and action afterwards can and should be evaluated.

Last but not least, it is important for the students to follow the whole process of problem-solving model step by step since half of managerial decisions failed because the decision makers took short cut and skipped critical steps of decision making (Nutt, 1999).

\section{The Case Study Materials}

To problem-solving approach above is applied to the author's Organizational Behavior class with a set of carefully-picked cases published in HBR over the past two decades. As one of the most influential business magazines for both management practitioners and academics, HBR publishes a three-to-four page long management case in each issue (currently 10 issues annually). These cases "present dilemmas faced by leaders in real companies" (Harvard Business Review, 2014), although the case contexts such as names and companies are "fictionalized." They reflect a wide range of management issues in management, leadership, strategy, marketing, business ethics, international business, and so on. In comparison with those more popular and lengthier HBS cases, the HBR cases are more focused on specific management problems, particularly those that test the soft skills of managers, without the somehow redundant corporate and industrial background information, tables, charts, and so on, which are popular in HBS cases. Therefore HBR cases are particularly suitable for case study in conceptual management courses like Organizational Behavior, for both undergraduate classes and junior MBA classes. Each HBR case scenario is followed by three or four experts' commentaries and analyses, which can provide good insights to instructors who use the cases under the problem-solving case study model. However, these respectable commentators - CEOs, executives, directors, entrepreneurs, consultants, or elite B-school professors - seldom share the same opinions of solutions to the same problem in the case. Despite the editorial preference, it mostly reflects how variable managers' choice of decisions could be in the real world even when they face the same decision situation. Instructors ought to mostly count on their own understanding and analysis of the case and develop alternative solutions based on their own knowledge, experience, and judgment.

Fourteen out of the hundreds of HBR cases that particularly fit the key topics on individual, group, and organizational behaviors respectively in the Organizational Behavior class have been selected over the years (see 
Table 1). Twelve of the 14 cases were published in the new millennium as lately as 2013 . The two cases published in 1996 were selected and retained because their contents and contexts are still highly relevant today, and no better HBR cases on the same topics have been published thereafter. Of course, the selection of the cases is regularly updated so that only those most relevant cases to the subjects and topics are retained.

Table 1. The14 HBR Cases For Developing Problem-Solving Skills In Organizational Behavior

\begin{tabular}{|c|c|c|c|c|}
\hline \multicolumn{2}{|c|}{ OB Topic ${ }^{1}$} & \multirow{2}{*}{$\begin{array}{r}\text { Case Title } \\
\text { Bonuses in bad } \\
\text { times }\end{array}$} & \multirow{2}{*}{$\begin{array}{l}\text { Brief Description } \\
\text { A supermarket chain in Spain needs to } \\
\text { decide whether to pay its employees } \\
\text { bonuses as usual despite a recession. }\end{array}$} & \multirow{2}{*}{$\begin{array}{c}\text { HBR Issue } \\
\text { July-August } 2012\end{array}$} \\
\hline Overview & Course Overview & & & \\
\hline \multirow{5}{*}{$\begin{array}{l}\text { Individual } \\
\text { Behavior }\end{array}$} & Perception & The micromanager & $\begin{array}{l}\text { A CEO thought his marketing director } \\
\text { was incapable but she felt her boss was } \\
\text { micromanaging her. }\end{array}$ & September 2004 \\
\hline & Attitude & $\begin{array}{l}\text { Why are we losing } \\
\text { all our good people? }\end{array}$ & $\begin{array}{l}\text { An architecture firm faces a brain drain } \\
\text { of talented employees. }\end{array}$ & June 2008 \\
\hline & Personality & $\begin{array}{l}\text { What a star - what a } \\
\text { jerk }\end{array}$ & $\begin{array}{l}\text { A new boss has to deal with a star } \\
\text { performer who constantly bullies his } \\
\text { colleagues despite her advice. }\end{array}$ & September 2001 \\
\hline & Decision Making & $\begin{array}{l}\text { All the wrong } \\
\text { moves }\end{array}$ & $\begin{array}{l}\text { A CEO and his management made } \\
\text { several bad decisions in a row. }\end{array}$ & January 2006 \\
\hline & Motivation & Growing pains & $\begin{array}{l}\text { An entrepreneur needs to reconsider his } \\
\text { compensation policies when his } \\
\text { superstar marketing manager is being } \\
\text { poached by a headhunter. }\end{array}$ & July-August 1996 \\
\hline \multirow{5}{*}{ Group Behavior } & $\begin{array}{l}\text { Group Dynamics } \\
\text { and Teamwork }\end{array}$ & $\begin{array}{l}\text { The strategy that } \\
\text { wouldn't travel }\end{array}$ & $\begin{array}{l}\text { An innovative teamwork strategy that } \\
\text { works well in one plant just doesn't } \\
\text { work at all in another. }\end{array}$ & $\begin{array}{l}\text { November- } \\
\text { December } 1996\end{array}$ \\
\hline & Communication & $\begin{array}{l}\text { They bought in. } \\
\text { Now they want to } \\
\text { bail out }\end{array}$ & $\begin{array}{l}\text { A CTO gets a hard time to persuade } \\
\text { other department heads to contribute } \\
\text { funds to his new customer relationship } \\
\text { management software. }\end{array}$ & $\underline{\text { December } 2003}$ \\
\hline & Leadership & $\begin{array}{l}\text { The very model of a } \\
\text { modern senior } \\
\text { manager }\end{array}$ & $\begin{array}{l}\text { A HR director's one-size-fits-all model } \\
\text { of leadership development is challenged } \\
\text { by the CEO and other executives. }\end{array}$ & January 2007 \\
\hline & Power and Politics & Into the fray & $\begin{array}{l}\text { A top performer who believes numbers } \\
\text { talk for themselves now has to deal with } \\
\text { a colleague who might become his new } \\
\text { boss thanks to her strong connections. }\end{array}$ & January 2005 \\
\hline & $\begin{array}{l}\text { Conflict and } \\
\text { Negotiation }\end{array}$ & $\begin{array}{l}\text { Take the money - or } \\
\text { run? }\end{array}$ & $\begin{array}{l}\text { The founders of a company are } \\
\text { negotiating with a venture capitalist who } \\
\text { might have breached their trust. }\end{array}$ & November 2004 \\
\hline \multirow{3}{*}{$\begin{array}{l}\text { Organizational } \\
\text { Behavior }\end{array}$} & $\begin{array}{l}\text { Structure and } \\
\text { Design }\end{array}$ & $\begin{array}{l}\text { Learning to play in } \\
\text { the new "share } \\
\text { economy" }\end{array}$ & $\begin{array}{l}\text { A car rental company needs to decide } \\
\text { how to integrate the car-sharing start-up } \\
\text { it just acquired. }\end{array}$ & July-August 2013 \\
\hline & $\begin{array}{l}\text { Organizational } \\
\text { Culture }\end{array}$ & Oil and wasser & $\begin{array}{l}\text { The HR director of a British company } \\
\text { and his German counterpart failed to } \\
\text { work out a leadership development plan } \\
\text { three months after their merger. }\end{array}$ & May 2004 \\
\hline & $\begin{array}{l}\text { Organizational } \\
\text { Change }\end{array}$ & $\begin{array}{l}\text { Welcome aboard } \\
\text { (but don't change a } \\
\text { thing) }\end{array}$ & $\begin{array}{l}\text { A new CEO wanted to change the } \\
\text { company's strategy and culture but felt } \\
\text { the strong resistance from the owner and } \\
\text { her own management team. }\end{array}$ & October 2002 \\
\hline
\end{tabular}

\footnotetext{
${ }^{1}$ Many cases can be used for more than the one topic designated in the table, up to the instructor's purpose and judgment. By the same token, there are also other HBR cases that might fit the topics in the table but are not included.
} 
Harvard Business School Publishing allows instructors to use in their classes only those HBR articles and cases with copyrights directly purchased from the publisher other than to assign the materials to the students and ask them to download from EBSCO Business Source. Therefore a digital course pack of the HBR cases is set up at the HBR publisher's web site so that the students can purchase copyrights and download the cases individually after registration at the web site. An advantage of the purchased digital copy cases to the instructor is that it does not come with the experts' commentaries, which are available to instructors upon request however.

\section{The Organization and Process of a Case Study Session}

A case study session with the problem-solving approach presented in this paper takes approximately 60-75 minutes and largely follows the three-stage model of case study process by Erskine, et al., (2003) - individual preparation, small group discussion, and class (big group) discussion. Students are required to carefully read the case and analyze it individually before class under the direction of a case study guide. The guide is provided by the instructor and is similar to the Problem-Solving Approach of Case Study section in this paper. Then they discuss the case in groups in classroom for 30 minutes, following the four steps of problem-solving model. All groups are requested to cover all four steps with their group discussion. The instructor walks around the classroom, addressing the students' questions.

Next, four groups will be called to the front of the classroom and write down on the whiteboard their opinions on one of the four steps of the problem-solving model, which is randomly assigned to a group by the instructor. Groups are told not to worry about the possible mismatch between their writings on one step and those of the other groups' on other steps since the mismatch problem, if any, would be addressed in the next step during class discussion. The remaining groups may be called to add their opinions to the steps that are finished first on the board by the previous four groups. The order and steps of group case analysis writing on the board will be rotated regularly over the semester. This part of the work may take up to 15 minutes.

Finally, after a brief, collective review of the case background information, the instructor will lead the class discussion for up to 30 minutes, covering and integrating the writings on each of the four steps on the whiteboard. Groups will be asked to explain or clarify their own writings if needed. The rest of the class will be asked for their comments about the writings, step by step, to contribute different or additional ideas, or to raise questions for either the focal group or the instructor. Then the instructor will give his feedback on the writings, ask questions on some parts of the writings, merge or combine some points on the board, move some points between steps (for example, move some points from the "problem" step to the "cause diagnosis" step), relate points between steps, and/or add some critical points or perspectives missed in the writings and discussion. Of course students are free to ask any questions during the instructor's wrap-up. In the end of the class discussion, the instructor summarizes the main learning outcomes of the case and its relevance to the course topic. Finally the instructor concludes the case session by asking whether students have any overall questions after all the individual, group, and class discussion and briefly addressing their questions if any. Over the whole process, students are advised again and again that there is no such things as correct or standard answers to a case; instead it all depends on whether they can well justify their analyses and support their points with sufficient evidence and facts from the case and the logic of their analyses.

In addition to the regular case study process above, three or four formal, 10-minute group presentations of case study are scheduled over the semester. Each time all groups in the class are asked to present their analyses on the same case so that group performance can be compared with each other. Each group's presentation will be evaluated by the instructor and the rest of the class on a 50-50 basis with a group presentation rubric. The instructor shares with the class his four-step analysis of the group presentation case with PowerPoint slides in the end after all the group presentations and evaluation are finished. He also provides detailed, written feedback on each group's presentation performance individually and summarizes and addresses common issues among groups in terms of both contents and format of their presentations in the next class.

Furthermore, given the teamwork nature of the case study approach, students are told from the very beginning of the class that they will be evaluated by their group peers in the end of the semester on their overall contribution (percentage range: $0-100 \%$ ) to all the case studies and especially the case presentations. Their 
individual grades on the group work will be determined by their group grades weighted by the average of peer ratings they received.

Another possible variation to the regular case study process above is that, if classroom time is constrained, such as in the case of overtime by other class activities in a three-hour session, the group writing-on-board step may be skipped; groups may be asked to present their opinions orally instead. Readers who are interested in using this approach of case study may consider requiring individual case study reports as well, which are not included in author's class due to other writing assignments.

\section{A SAMPLE CASE STUDY WITH THE PROBLEM-SOLVING APPROACH}

\section{The Sample Case Scenario}

In this part, the paper uses the case "Why Are We Losing All Our Good People?" by Lawler (2008) as an example of case study to demonstrate how the problem-solving case study approach is used in the author's Organizational Behavior class to help students develop their problem-solving skills. The following paragraph is a sketchy summary of the case for the sake of the paper's demonstration; readers are strongly encouraged to read the four-page full case published in the June 2008 issue of $H B R$ (pp. 41-45) so as to better understand the case situation and the author's case analyses.

Sambian Partners is an architecture and engineering firm based in Chicago with offices in San Francisco, New York, and Los Angles as well. Its founder Peter Gasbarian wanted to build Sambian into a top-notch firm especially appealing to young architects and highlighting innovation. Helen, Peter's daughter and an award-winning architect, took over the leadership of the firm after Peter's death. She emphasized teamwork among the firm's architects, engineers, and sales people. Recently Sambian's Chicago office had lost three talented designers Tom, Pat, and Irena due to various "personal reasons." Another very promising young architect Adrienne was about to follow their footprints if it had not been because of Helen's exceptional counteroffer of promotion to retain her. However, Mary, Sambian's HR director, strongly disagreed with Helen about the promotion of Adrienne and challenged the promotion's necessity and fairness as well as Adrienne's seniority and competency. She thought the departures of the three architects were merely coincidences due to different personal causes but neither a trend nor the firm's fault. Her annual employee satisfaction survey as wells her exit interview with Tom turned out little valuable information to Helen about why young talents at Sambian were leaving. On the other hand, Tom revealed his disappointment at the firm's management and the glass ceiling of his career to his wife when he quit. Young architects at Sambian complained among themselves about the incapable, uninspired, and unsupportive "deadwood" middle managers, including Paul the architecture sales manager and Bob the vice president of engineering. Some of them even put their complaints on the employee survey for the open questions. But HR director Mary did not take it seriously since all the numbers from the survey looked good anyway. CEO Helen did not believe the results of the survey but could not figure out what went wrong at Sambian either. (Lawler, 2008)

\section{The Sample Case Analyses}

The following descriptions reflect the classroom outcomes of the case study accumulated over the years by the author. It is mostly the understanding and analyses of the author as the instructor, although it may include some contribution from the author's previous classes as well as some inspiration from the case commentators. In addition to the primary purpose of demonstrating how the problem-solving model is used in case study in the author's class, these analyses can also be used as a reference or quasi-teaching notes by those readers who are interested in using this case in their Organizational Behavior or Management classes. Readers may find that these analyses are more logical, better organized, and more thorough and insightful than the four experts' commentaries following the case in the original HBR issue. But the author's analyses are by no means meant to provide a standard answer to the case or a benchmark case study. 
Identifying problem. The primary problem that Sambian or CEO Helen needed to solve in the case was how to stop the firm's brain drain and retain its young talents, although the case title and the end statement of the case might make the students to mistake the problem as how to find out what has caused Sambian's good people to quit. The loss of three key designers (and a nearly fourth) at Sambian was already a trend, despite HR director Mary's wishful ignorance and poor judgment. The so-called "personal reasons" were merely political correct excuses to cite when employees jumped the ship. There must have been organizational reasons beneath the iceberg of personal reasons if key talents departed in a row in such a short period of time.

Diagnosing causes. This case is purposely chosen for the chapter about job attitude. Job satisfaction is a primary job attitude, and job dissatisfaction sometimes causes employee turnover (Robbins \& Judge, 2015). This is the main OB theory that should be emphasized in analyzing the causes of Sambian's brain drain problem. Students should be further encouraged to find out what has caused the employees' and especially those young architects' high job dissatisfaction with evidence and facts from the case. Three primary causes of job satisfaction can be identified through a thorough understanding of the case - incapable middle managers, mismatched HR policies procedures, and misfit culture for young talents. First of all, the case showed the incompetency of three middle managers: Mary, Paul, and Bob. Mary the HR director bore the old fashioned HR mindset that cares more about HR procedures and fairness than retaining talents and supporting corporate strategy. She also failed to identify the brain drain as a trend, and her employee survey was out of touch and thus useless. Paul the head of sales was considered uninspired by young architects and failed to provide strong support for Tom's gorgeous design. Bob the vice president of engineering did not know how to mentor young talents and lost Tom and almost lost Adrienne, two talented and accomplished young architects. And there were other deadwoods in the firm as well. Second, Sambian's HR policies and practices in compensation and promotion mismatched its mission and strategy defined by its founder to build the firm into a place for young talents to make their marks. Instead, Mary the HR director prioritized seniority and procedures over competency and performance. Finally, Sambian's bureaucratic, seniority-based, and deadwood-led culture does not meet young talents' expectations for growth and development although the firm desperately needs to count on the creativity and innovativeness of its young architects and engineers in the architecture business.

Prescribing alternatives. In order to solve the brain drain problem at Sambian and retain and develop the firm's young talents, CEO Helen faced two alternatives. Her first option was to follow HR director Mary's advice, i.e., taking Adrienne's promotion as an exception and keeping the firm's current seniority-based HR policies and management structure and practices unchanged. The advantages of this alternative include that it would be easy, less expensive, and less risky to carry out; and it could maintain the fairness of the firm's HR system and reward employees' loyalty. But its disadvantages were also obvious - it might not be able to prevent young talents from leaving since it would not change the bureaucratic culture and management practices at Sambian. The other alternative was to take Adrienne's case as the beginning, reshuffling the firm's management team and changing Sambian's HR policies and corporate culture. This alternative would directly address the brain drain problem and might re-assure the firm's original mission of attracting and retaining young talented architects in the long run, despite HR director Mary's disagreement about the urgency of the problem. But it was riskier and more costly than the first alternative and might cause turbulence in the company, especially among managers.

Making a decision and its implementation plan. Based on the previous diagnosis of causes, the second alternative looks more promising in solving the problem. The subsequent action plan to implement the decision embodies two major phases. In the short run (one to three months), CEO Helen would need to conduct a talent inventory, identifying young, promising designers and engineers by the $80 / 20$ principle, developing specific plans for their development in the firm, and carrying out the plan step by step. She would need to re-declare the firm's mission of growing young talents, regularly interact with young architects and engineers herself through an open door policy or other formal or informal channels, and encourage other managers to do so as well. She might also want to let HR director Mary resign and replace her with a new HR chief who could better understand the concept of talent management and was experienced in recruiting and retaining talents for medium-sized, professional firms such as architecture firms, law offices, or consulting firms. In the long run (one to two years), Helen would need to gradually replace some of the "deadwood" middle managers such the sales chief Paul and the engineering VP Bob if they could not better develop or support the architects and engineers. Another change Helen would need to make in the long run is to ask the new HR chief to modify the firm's HR policies and practices (especially those about 
compensation and promotion) to better suits the founder's vision that makes the firm a good place for young talents to make their mark. Finally, Hellen might also consider reorganizing the firm into a more team-based, flat structure, which could reduce the current hierarchy and bureaucracy of the firm and boost the young talents' morale through empowerment and teamwork.

As a conclusion of the sample case study, the following learning outcomes ought to be highlighted to the students in the end. First, serial employee turnover in a company often signals its workforce's job dissatisfaction, which in turn reveals that the company's HR policies and practices must be problematic. Second, companies need to regularly audit and adjust their HR policies and practices if needed and assure they are in alignment with the company's mission and strategy. Third, HR managers need to regularly upgrade their mindset and skills from traditional personnel management of paperwork and documentation to talent retention and development that support the corporate strategy and business growth. Last but not least, teamwork and empowerment can better motivate today's young professionals and improve their organizational commitment and productivity.

\section{DISCUSSION AND IMPLICATIONS}

As the Literature Review and Methods parts revealed above, the problem-solving approach of case study per se is nothing new to management education. What makes this paper special is how it extends this well-developed approach to a new context in a systematic way toward a significant but long-ignored learning goal in management education - developing problem-solving skills in conceptual management courses. Readers might have realized that the conceptual foundation of the problem-solving approach of case study presented in this paper is solid; the procedures of the approach are appropriate; and the teaching materials it adopted are popular and relevant. But what about the effectiveness of this pedagogy?

As case teaching guru Christensen commented, "There are few tasks more difficult than evaluating the effect of our teaching. Trying to gauge success is like tossing coins into the Grand Canyon and waiting to hear the clink." (Christensen, 1991, p. 114). Thus he eventually sought to the satisfaction from the case teaching process itself other than any immediate, tangible outcomes. The popularity of applying the problem-solving approach of case study to 14 HBR cases among the students has been overwhelming among all Organizational Behavior classes taught by the author over the years, as shown by both the broad, active participation by the students in the case study sessions and their constantly positive comments about the approach in their teaching evaluation. The author's Organizational Behavior class was therefore often named one of the most interesting and beneficial courses by MBA students.

In addition to the students' enjoyment of the pedagogy, more salient and substantial improvement in the students' problem-solving skills was often observable over the semester. Usually their first few case studies, including the first group case presentation, were somewhat shallow, biased, less-focused, and with solutions and action plans lack of operational details. Later as the class proceeded and more cases were studied, however, the students' analyses became more and more in-depth and logical; their solutions and implementation plans were more and more realistic and practical. The last group case study presentation, which was scheduled nearly the end of the class, particularly showed their learning achievements in both course contents and managerial thoughts. In addition, the students' learning accomplishments in problem-solving skills were also noticeable with the case studies on their midterm and final exams.

The students' learning effectiveness of problem-solving skills through the serial HBR case study was sometimes demonstrated in other occasions as well. For example, these students did much better when they took other classes that also used case study and worked with peer students who had not been exposed to the problemsolving case study of the 14 HBR cases; or when they took part in extra-curricular activities such as inter-collegial case study contests. Last but not least, although lack of formal alumni survey, the author often heard back from former students who had left campus for years about how impressed they were with the problem-solving case study in their Organizational Behavior class and how their good habits of following the four-step problem-solving model and engaging in in-depth analysis helped them in their daily work as a manager to solve actual problems. This is a clear reflection of the long-term impact of Bloom's affective learning (Bloom et al., 1956) on students' career through the problem-solving case study in classroom. 
It needs to point out that, although it is extensively used in the author's Organizational Behavior class, the problem-solving case study is by no means the whole learning experience of students in the class. There are many other learning activities and several major assignments in the same class as well. In classroom, approximately half of the time is used for lecturing and discussing subject knowledge and conducting other experiential activities, including role play, videos, exercises, and so on. After class, students need to conduct a big field research project in groups and complete other writing assignments (such as prepare a personal case study report reflecting their personal experience relevant to Organizational Behavior). Of course, students also have to take quizzes and exams, which were mostly based on course knowledge, as they normally do in other business classes.

Like any other management pedagogies, the problem-solving approach of case study presented in this paper also has several limitations that need to clarify and improve, despite its apparent relevance and overall effectiveness in developing students' problem-solving skills. First of all, there is a need for a stricter, direct evaluation on the effectiveness of the pedagogy than the informal feedback results discussed above. Although it allowed indirect assessment of learning goals, AACSB (2013) made it clear that indirect measures (such as feedback survey) are only complementary but no substitute for direct assessment of learning. In addition to the more informal evaluation of the pedagogy's effectiveness, the current assessment of the problem-learning skills as an Assurance of Learning goal in the author's Organizational Behavior class is merely the case study on the final exam of the class. This is far from sufficient to systematically evaluate the pedagogical effectiveness of the approach. The author is planning a more vigorous assessment of the problem-solving approach of case study with two equivalent cases for pre-test (at the very beginning of the class) and post-test (can be combined with the final exam) respectively, with panel ratings by three or four experts following a rating rubrics of problem-solving skills.

The second limitation is that the effectiveness of learning problem-solving skills through studying the HBR cases is sometimes subject to the attitude and readiness of the students. MBA students in the author's Organizational Behavior class generally tended to be more enthusiastic about the pedagogy and better prepared for case study in class than undergraduate students. This situation is in alignment with the general disparity between graduate and undergraduate students in terms of learning motivation in other business classes or other disciplines as well. Undergraduate students in non-elite schools might especially feel bored with repetitive training with the same approach. Thus instructors who are interested in applying the pedagogy and the HBR cases to their undergraduate classes might want to adjust the number of HBR cases and add more experiential activities of other types so as to increase the variety of their classes.

Thirdly, it must be pointed out that all HBR cases take the perspective of the manager or management in a company. Consequently the case study approach in this paper emphasizes that students take the employer's role in solving managerial problems. This is obviously biased and might create difficulties especially for in-experienced undergraduate students (Mesny, 2013). Although the primary goal of management education is to develop managers, students need to be alerted of this difference and encouraged to maintain a more objective, balanced perspective. This is both a scientific and ethical issue to managers.

Last but not least, occasionally a handful of students who use the $14 \mathrm{HBR}$ cases might try to obtain the experts' commentaries through EBSCO Business Source. Instructors have to be aware of this possibility and monitor to what degree the students' participation and presentation in class is similar to the experts' opinions. If remarkable or frequent duplication were found, the instructor need to reemphasize to the class that case study is not a game to seek the right answer; instead, practicing the problem-solving process and building up their own problemsolving skills through personal experience is more valuable than copying the experts' ideas. Moreover, not all the experts' commentaries are smart; some of them could be out of touch and/or controversial, as shown by the commentaries for the sample case "Why Are We Losing All Our Good People." Of course, students are allowed to read the experts' commentaries after the case is discussed or presented in class. Then they would realize how different the class discussion under an experienced instructor could be from the experts' opinions. The instructor may further highlight the originality and authenticity of students' contribution to case study when grading the students' participation and presentation. 


\section{CONCLUSION}

Problem-solving is a managerial routine, and problem-solving skills are part of the competency set and a critical learning goal for all business students. There is no question that conceptual management courses like Organizational Behavior also need to develop business majors' problem-solving skills as well as other more quantitative and practical courses do. The question is how management instructors can find a feasible and valid way to teach problem-solving skills in their more conceptual courses by nature.

The work presented in this paper is one of the experimental efforts in making traditionally more conceptual management courses more practical and relevant in developing business students' street smart as well as book smart. It was drawn upon two well-established pedagogies - one cross-disciplinary and one focused on management education, adapted a widely acknowledged management model, identified a niche of highly relevant and everupdated source of teaching materials, successfully implemented the model in classroom for years, and showed constantly positive results in developing business students' problem-solving skills. Management instructors, especially those who teach Organizational Behavior or Management courses, can surely benefit directly from the details of developing students' problem-solving skills with case study presented in this paper, either fully or partially. More importantly, as Erskine et al., (2003) pointed out, management instructors should be encouraged by this paper to find their own "comfort zone" in applying case teaching or other pedagogies to their classroom so as to achieve their learning goals of building problem-solving skills or other business competency, depending on their experience, the course subject, the students, and so forth.

\section{AUTHOR INFORMATION}

Wei He is an Associate Professor of Management in the Donald W. Scott College of Business, Indiana State University. He received his Ph.D. in organization studies from Boston College. His research interests include organizational change, cross-cultural/international management, and corporate citizenship. He has published in such journals as Organization Science, Journal of International Management, and so on.

\section{REFERENCES}

AACSB International. (2013). AACSB assurance of learning standards: An interpretation. Retrieved August 15,2014 from http://www.aacsb.edu/ /media/AACSB/Publications/white-papers/wp-assurance-of-learningstandards.ashx.

Anonymous. (2001). Undergraduate institutions with faculty members using PBL. PBL Insight, 3(3), 14.

Barnes, L. B., Christensen, C. R., \& Hansen, A. J. (1994). Teaching with the Case Method ( $3^{\text {rd }}$ Ed.) Boston, MA: Harvard Business School Press.

Bigelow, J. D. (2004). Using problem-based learning to develop skills in solving unstructured problems. Journal of Management Education, 28(5), 591-609.

Bilimoria, D., \& Fukami, C. (2002). The scholarship of teaching and learning in the management sciences: Disciplinary styles and content. In M.T. Huber \& S.P. Mooreale (Eds), Disciplinary Styles in the Scholarship of Teaching and Learning. Exploring common grounds (pp. 125-142). Merrifield, VA: American Association for Higher Education.

Bloom, B. S., Engelhart, M. D., Furst, E. J., Hill, W. H., \& Krathwohl, D. R. (Ed.) (1956). Taxonomy of educational objectives: The classification of educational goals. Handbook 1: cognitive domain. New York: David McKay.

Brownwell, J., \& Jameson, D. (2004), Problem-based learning in graduate management education: An integrative model and interdisciplinary application. Journal of Management Education, 28, 558-577.

California State University, Long Beach. (2014). Core Courses Assessment Schedule and Reports, College of Business Administration. Retrieved October 16, 2014 from http://www.csulb.edu/colleges/cba/aacsb/core-courseschedule/

Christensen, C. R. (1991). Every student teaches and every teacher learns: the reciprocal gift of discussion teaching. In C. R. Christensen, D. A. Garvin \& A. Sweet (Eds.), Education for Judgment: the Artistry of Discussion Leadership (pp. 99-119). Boston: Harvard Business School Press.

Daft, R. L. (2014). Management $\left(11^{\text {th }}\right.$ Ed.) Mason, OH: Southwestern.

Erskine, J. A., Leenders, M. R., \& Mauffette-Leenders, L. A. (2003). Teaching with Cases ( $3^{\text {rd }}$ Ed.) London, Ontario: Ivey Publishing. 
Gordon, J. (2002). Organizational Behavior: A Diagnostic Approach $\left(7^{\text {th }}\right.$ Ed.) Upper Saddle River, NJ: Prentice Hall.

Hambur, S., Rowe, K., Tu Luc, L., \& Australian Council for Educational Research. (2002). Graduate skills assessment. Stage one validity study. Canberra, Australia: DEST.

Harvard Business Review. (2014). HBR's fictionalized case studies. Retrieved October 16, 2014 from http://hbr.org/magazine.

Hill, C. W. L., Jones, G. R., \& Schilling, M. A. (2015). Strategic Management: An Integrative Approach (11 ${ }^{\text {th }}$ Ed.) Stamford, CT: Cengage Learning.

Hmelo-Silver, Cindy E. (2004). Problem-based learning: What and how do students learn? Educational Psychology Review, 16 (3), 235-266.

Illinois State University. (2010). Assessment Plan, Department of Management \& Quantitative Methods, College of Business. Retrieved October 16, 2014 from http://assessment.illinoisstate.edu/downloads/plans/cob/mqm/B.S.inManagement.pdf

Indiana State University. (2013). Undergraduate business core curriculum learning goals. Scott College of Business, approved September 20, 2013.

Kinicki, A. \& Williams, B. (2013). Management: A Practical Introduction (6 ${ }^{\text {th }}$ Ed.) Boston, MA: McGraw-Hill.

Knight, P., \&Yorke, M. (2001). Employability through the curriculum. Open University, England: Skills Plus Project.

Kotter, J. (2001). What leaders really do? Harvard Business Review, December, 85-96.

Krathwohl, D. R. (2002). A revision of Bloom's taxonomy: An overview. Theory into Practice, 41, $212-218$.

Landry, M. (1995). A note on the concept of 'problem'. Organization Studies, 16, 315-343.

Lawler, E. E., III. (2008). Why are we losing all our good people? Harvard Business Review, June, 41-65.

Leavitt, H. J. (1989). Educating our MBAs: On teaching what we haven't taught, California Management Review, 31(3), 38-50.

Luthans, F. (1988). Successful vs. effective real managers. Academy of Management Executives, 2(2), 127-132.

Martell, K. (2005). Overcoming Faculty Resistance to Assessment. In K. Martell \& T. Calderon (Eds.), Assessment of student learning in business schools: Best practices each step of the way (Vol. 1:2, 210-226). Tallahassee, FL: Association for Institutional Research.

Martell, K. (2007). Assessing student learning: Are business schools making the grade? Journal of Education for Business. March - April, 189-195.

Mauffette-Leenders, L. A., Erskine, J. A., \& Leenders, M. R. (2001). Learning with Cases (2 ${ }^{\text {nd }}$ Ed.) London, Ontario: Ivey Publishing.

Maxwell, G., Scott, B, Macfarlane, D., \& Williamson, E. (2010). Employers as stakeholders in postgraduate employability skills development. International Journal of Management Education, 8(2), 1-11.

Mesny, A. (2013). Taking stock of the century-long utilization of the case method in management education. Canadian Journal of Administrative Sciences, 30, 56-66.

Miller, J. S. (2004). Problem-based learning in organizational behavior class: Solving students' real problems. Journal of Management Education, 28(5), 578-590.

Mintzberg, H. (2004). Managers, not MBAs. A hard look at the soft practice of managing and management development. San Francisco: Berrett-Koehler.

Mo, J., \& He, W. (Forthcoming). The organizational change dilemma of ERP implementation in a small manufacturing company. Journal of Business Case Studies, accepted.

Nutt, P. (1999). Surprising but true: Half the decisions in organizations fail. Academy of Management Executive, 13(4), 75-90.

Pfeffer, J., \& Fong, C. T. (2002). The end of business schools? Less success than meets the eye. Academy of Management Learning \& Education, 1(1), 78-95.

Porter, L. W., \& McKibbin, L. E. (1988). Management education and development: Drift or thrust into the 21 st century? New York: McGraw-Hill.

Pounds, W.F. (1969). The process of problem finding. Management Review, 11(1). 1-18.

Robbins, S. P., \& Judge, T. A. (2015). Organizational Behavior (16 ${ }^{\text {th }}$ Ed.) Upper Saddle River, NJ: Pearson Education.

Schmidt, H. G, Rotgans, J. I., \& Yew, E. H. J. (2011). The process of problem-based learning: What works and why. Medical Education, 45 (8), 792-806.

Shermerhorn, J. R. (2013). Management (12 ${ }^{\text {th }}$ Ed.) Hoboken, NJ: John Wiley \& Sons.

Shonk, J. H. (1997). Team-based Organizations. Chicago: Irwin.

Smith, F. F. (2005). Problem-based learning: Can it improve managerial thinking? Journal of Management Education, 29(2), 357-378.

Smith, G. (1987). The use and effectiveness of the case study method in management education: A critical review. Management Education and Development, 18, 51-61. 